\title{
Low oxygen treatment prior to cold storage decreases the incidence of bitter pit in 'Golden Reinders' apples
}

Jesús Val ${ }^{\mathrm{a}, *}$, Victoria Fernández ${ }^{\mathrm{a}}$, Paola López ${ }^{\mathrm{a}}$, Jose María Peiró ${ }^{\mathrm{b}}$ and Alvaro Blanco ${ }^{\mathrm{a}}$

${ }^{a}$ Estación Experimental de Aula Dei-CSIC. Avda. Montañana 1005, 50059-Zaragoza, Spain Alimentos de Origen Vegetal, University of Zaragoza, Miguel Servet 177, 50013 Zaragoza, Spain

Running Title: Low Oxygen and bitter pit

\begin{abstract}
BACKGROUND: The effect of subjecting 'Golden Reinders' apples to a low $\mathrm{O}_{2}$ pretreatment (LOT; $1-2 \% \mathrm{O}_{2}$ ) was evaluated as a strategy to decrease the rate of bitter pit (BP) incidence after standard cold storage (ST). Immediately after harvest, apples were stored for 10 days at $20{ }^{\circ} \mathrm{C}$ under low $\mathrm{O}_{2}$. Thereafter, apples were cold-stored $\left(0-4{ }^{\circ} \mathrm{C}\right)$ for 4 months and changes were monitored in terms of BP incidence, fruit quality traits and mineral element concentrations.
\end{abstract}

RESULTS: After 4 months cold storage, LOT apples presented a 2.6-fold decrease in the rate of BP incidence (14\%) versus the values obtained for standard cold-stored fruits (37\% BP incidence). The LOT increased flesh firmness, total soluble solids and titratable acidity as compared to the quality traits determined for cold-stored fruits. Lower cortex $\mathrm{Ca}$ and $\mathrm{Mg}$ concentrations as compared to ST apples were determined in association with LOT, 2 months after cold-storage. 
CONCLUSION: Application of a LOT prior to cold-storage may be a promising strategy to reduce the incidence of BP and preserve fruit quality, which should be further investigated.

Keywords: Apple; Bitter pit; calcium-related disorders; fruit quality; low oxygen; storage

* Correspondence to: Jesús Val, Plant Nutrition Department, Estación Experimental de Aula Dei-CSIC, Avda. De Montañana 1005, 50059 Zaragoza, Spain

E-mail: jval@eead.csic.es

\section{INTRODUCTION}

Bitter pit (BP) is a common calcium (Ca)-related disorder of apple (Malus x domestica Borkh), which may limit the marketability of fruits and lead to major economic losses ${ }^{1}$. Despite such apple disorder has been a matter of scientific interest for more than 100 years, there is still a considerable lack of knowledge on the complex mechanisms that trigger its occurrence. ${ }^{2,3}$ While BP develops during post-harvest storage, the underlying process stem from the period of fruit growth and development ${ }^{2}$. Development of BP has been associated with localised Ca deficiency and mineral element imbalances in the affected tissues. ${ }^{2-5}$

Recent investigations have shown that corky BP spots have higher concentrations of Ca, magnesium $(\mathrm{Mg})$ and potassium $(\mathrm{K})$, higher polyphenol oxidase activities and lower concentrations of all carbohydrates. ${ }^{6}$ Analysis of the polypeptide pattern of BP affected tissues showed the occurrence of a novel potential protein which might be either an inhibitor 
of pectinmethylesterase, a small heat stress protein (smHSP) or a product of the Ypr-10 gene family identified as 'Mal d 1', the main allergen of apples ${ }^{7}$. Several hypotheses chiefly related to fruit Ca homeostasis problems have been proposed to explain the development of BP injuries, ${ }^{2,3}$ which however did not yet enable the implementation of specific strategies to prevent or control its occurrence in practical terms. Recent studies suggest that Ca deficiency may be caused by factors such that may alter normal tissue Ca homeostasis (e.g. due to the level of gibberellins and/or $\mathrm{ABA}^{3,8}$; or affected by Ca membrane transporters ${ }^{9}$ ).

Apple storage at low $\mathrm{O}_{2}$ and/or high $\mathrm{CO}_{2}$ atmospheres has been shown to hamper the production of ethylene, thereby extending the storage life of fruits. ${ }^{10,11}$ On the other hand, controlled atmosphere treatments based on low $\mathrm{O}_{2}$ and specific temperatures have been proposed as an alternative to the use of agrochemicals for the control of biotic disorders. ${ }^{12-14}$ There are few studies available regarding the effect of low $\mathrm{O}_{2}$ pre-treatments on the development of physiological disorders or improving fruit quality. ${ }^{15}$ Wang and Dilley, ${ }^{16}$ Zanella $^{17}$ and more recently, Pesis et al. ${ }^{18}$ showed that low $\mathrm{O}_{2}, 20^{\circ} \mathrm{C}$ short-term pretreatments prior to cold storage could decrease significantly the rate of apple scald incidence during cold storage of scald-susceptible apple varieties. Only a meeting abstract relating to the effect of controlled-atmosphere low $\mathrm{O}_{2}$ pre-treatments in reducing the incidence of BP could be found, ${ }^{19}$ which motivated the development of this preliminary investigation.

\section{EXPERIMENTAL}

\section{Fruit source, pre-treatment and storage conditions}

‘Golden Reinders’ apples were collected from a commercial orchard located in Alfamen (Middle Ebro Valley, Spain). Apples picked at the time of optimum commercial harvest (18 September, 2008), were randomly selected and placed in boxes containing around $15 \mathrm{~kg}$ apples corresponding to 
approximately 80-90 fruits per box. A sample of fruits was randomly selected to record fruit quality parameters. Two sets of 16 boxes were made, and each set was treated according to a different strategy: one set of boxes was directly stored for 4 months under standard cold conditions (ST; $4^{\circ} \mathrm{C}$ ). The other set of fruits was subjected to a low $\mathrm{O}_{2}$ pre-treatment (LOT) at $1-2 \% \mathrm{O}_{2}$ and $20{ }^{\circ} \mathrm{C}$ for 10 days immediately after harvest, and was subsequently cold-stored as described for the ST treatment. For LOT, the apple boxes were placed inside a large plastic bag specially designed for CA storage. The bag was sealed and the concentration of $\mathrm{O}_{2}$ was kept below $2 \%$ by both applying vacuum and flushing $\mathrm{N}_{2}$ inside the bag when it rose above $2 \%$. The concentration of $\mathrm{O}_{2}, \mathrm{CO}_{2}$ and ethylene was measured by Gas Chromatography (GC) on a daily basis as described by González et al. ${ }^{20}$ Gas samples collected from inside the bag were taken with a $100 \mu \mathrm{L}$ Hamilton Gastight 1710N syringe (Hamilton Co., Reno, NV, USA) and the concentrations of $\mathrm{O}_{2}, \mathrm{~N}_{2}$ and ethylene were determined by Gas Chromatography (Hewlett Packard 4890, Avondale, PA, USA) equipped with a thermal conductivity detector and a CP-Carboplot (Chrompack, Middelburg, The Netherlands), capillary column (25 m) with a film thickness of $25 \mathrm{~mm}$, and an internal and external diameter of $0.53 \mathrm{~mm}$ and $0.75 \mathrm{~mm}$, respectively, using Helium as carrier gas $\left(12.6 \mathrm{~mL} \mathrm{~min}^{-1}\right)$. Ethylene, was measured by GC-FID (Hewlett Packard 4890, Avondale, PA, USA) equipped with a $1.83 \mathrm{~m}$ long, $3 \mathrm{~mm}$ external diameter and 2.1 mm internal diameter stainless steel column packed with 80-100 mesh Porapak QS (Supelco, Bellefonte, PA) using $\mathrm{N}_{2}$ as carrier gas.

Apples were cold-stored for 4 months at 0 to $4^{\circ} \mathrm{C}$, directly after harvest (control treatment, ST; 16 boxes containing $15 \mathrm{~kg}$ apples) or after LOT.

\section{Determination of BP incidence}

The rate of BP incidence in standard (ST) and LOT cold-stored and apples was visually evaluated on 7 different dates along the 4 months of cold storage, recording the number of fruits affected by BP with regard to the total number of fruits stored per treatment. An apple was 
considered as affected by BP when at least 1 corky spot was detected per fruit. The incidence of BP in presented according to the sampling days expressed as days after the harvesting date (DAH).

\section{Evaluation of fruit quality traits}

Samples of 4 random fruits with 16 repetitions were collected per treatment, at the time of harvest and, after 4 months of cold storage, 10 fruits per box (16 repetitions) were taken. Each individual fruit was weighed and its diameter recorded. Quality traits were assessed in 2 opposite sides of the same fruit by measuring: flesh firmness (using an Effegi penetrometer fitted with an 8-mm tip, Bertuzzi, Brugherio, Italy), total soluble solids content (SSC, determined with an ATAGO PR-101 digital refractometer, Atago Co., Tokyo, Japan), titratable acidity (TA) and L*a*b* colour (using a CR-200 chromometer, Minolta Co., Osaka, Japan). Soluble solids content and TA was determined after juice extraction using an electric blender.

\section{Mineral element determination}

Fruit tissue $\mathrm{K}, \mathrm{Mg}$ and $\mathrm{Ca}$ concentrations were analysed at the time of harvest and after 2 months of cold storage ( $\mathrm{g} \mathrm{kg}^{-1}$ fresh weight, FW). For mineral element determination, 2 apples per treatment (16 repetitions) were randomly selected and carefully washed in $0.1 \%$ detergent, followed by rinsing in tap water, $0.1 \mathrm{~N} \mathrm{HCl}$, and 2 baths in double-distilled water. A section 1-cm wide was cut along the equator of the fruit, collecting only the cortex and discarding the core. Subsequently, the peel was carefully separated from the cortex and both tissues were stored for mineral element determination. Peels were finely cut ( $<1 \mathrm{~mm}$ pieces), and $0.5 \mathrm{~g}$ were taken for the analysis. Cortex tissue was cut into small pieces and 2 g were consequently wetdigested using $10 \mathrm{~mL} \mathrm{HNO}_{3}$ and $2 \mathrm{~mL} \mathrm{H}_{2} \mathrm{O}_{2}$ on a hot plate. Once the samples were dry, they were dissolved in $10 \mathrm{~mL} \mathrm{HCl}$ and $15 \mathrm{~mL} \mathrm{H}_{2} \mathrm{O}$ were added. Calcium, $\mathrm{Mg}$ and $\mathrm{K}$ were 
measured by Atomic Absorption/Emission Spectroscopy (Thermo Scientific iCE 3300 AA Spectrophotometer, Cambridge, UK).

\section{Statistical analysis}

The trial was organised following a complete randomization. Fruit quality and mineral element analysis data were analyzed by ANOVA as a linear general model, and when significant, means were separated by the Duncan's multiple range test using the statistical programme SPSS 15.0. ANOVA of BP incidence was carried out with the angular transformation of data, as a univariate general model and means were separated as indicated above (16 repetitions per treatment). Data corresponding to the rate of BP over time were fitted to a sigmoid curve, ${ }^{21}$ and the resulting parameters were analysed as mentioned above.

\section{RESULTS AND DISCUSSION}

\section{Rate of BP incidence}

The rate of BP incidence of 'Golden Reinders' apples fitted to sigmoid lines against storage time (DAH) is shown in Fig. 1. In average the determination coefficient obtained from regression analysis of curve fitting was 95.20, and in all cases, analysis of variance resulted in significant fittings. The LOT was found to have a significant effect in reducing the rate of BP incidence as compared to the levels determined for standard cold-stored fruits.

Analysis of the parameters resulting from curve fitting showed that the theoretical maximum BP development decreased significantly in fruits subjected to LOT (Table 1, column 3) as compared to ST. This effect was confirmed by direct analysis of final data on BP incidence, as ANOVA of the transformed values at the end of the cold storage period (Table 1, column 2) resulted in significant differences between treatments. Besides, a retarding effect of the date of maximum BP occurrence was found (Table 1, column 5; this 
was predicted to happen $60 \mathrm{DAH}$ in the case of ST versus $76 \mathrm{DAH}$ calculated for LOT). However, it is remarkable to note that apples subjected to both treatments had theoretically a similar daily potential to develop BP injuries as derived from the maximum BP incidence rate values obtained (\% day ${ }^{-1}$; Table 1 , column 4$)$.

Thereby, it was found that the LOT reduced by 2.6-fold the rate of BP incidence and retarded the development of BP (i.e., 76 versus 60 DAH for LOT and ST, respectively) over the cold storage period. The mechanisms by which the pre-treatment may retard the rate of development or/and decrease the incidence of such disorder remain unclear, but it seems reasonable to think that some aerobic process involved on the initial development of BP may have been prevented or delayed in time due to $\mathrm{O}_{2}$ shortage.

\section{Quality traits evolution after storage}

Data relating the quality attributes of apples as measured directly after harvest or after 4 months cold-storage are shown in Table 2. The external appearance of LOT and ST apples 4 months after cold storage can be observed in Fig. 2. The results obtained indicate that the LOT had a positive effect with regard to preserving fruit firmness. Fruits pre-treated with low $\mathrm{O}_{2}$ had higher SSC and TA values as compared to those measured for ST apples.

Concerning chromaticity estimations, significant changes associated with the LOT were observed for L and a*, indicating that LOT fruits had a higher lightness intensity and acquired a more yellowish coloration (i.e., a lower degree of green intensity as derived from the less negative $b^{*}$ values) as compared to the CIE Lab values measured for ST fruits, which remained greener. (Table 2, Fig.2). Furthermore, 4 months after storage, fruits subjected to LOT had a smooth surface and an excellent appearance while ST apples shrivelled up, maybe due to a more rapid rate of dehydration in absence of the LOT. 


\section{Mineral element distribution after storage}

The tissue concentration of the major mineral elements influencing BP development (i.e., Ca, $\mathrm{Mg}$ and $\mathrm{K}$ ) as determined at the time of harvest and after 2 months cold storage is shown in Table 3. The low $\mathrm{O}_{2}$ pre-treatment had a major effect in reducing $\mathrm{Ca}$, and to a lower extent Mg, cortex concentrations as compared to the apparent cortex Ca and Mg accumulation taking place after cold-storing fruits directly after harvest. An inverse phenomenon was observed for cortex $\mathrm{K}$ concentrations, where the highest levels determined 2 months after storage were measured for LOT fruits. In contrast, no significant mineral element changes in association with the pre-treatment were observed in the peel of 'Golden Reinders' apples 2 months after cold-storage.

A redistribution of mineral elements within apple following convectional and low $\mathrm{O}_{2}$ storage has been reported previously. ${ }^{22,23,24}$ According to Perring and Pearson, ${ }^{23,24}$ after 25 weeks storage, apples kept at $1.25 \% \mathrm{O}_{2}$ had lower peel Ca and Mg concentrations in contrast to the higher Ca and Mg values measured on the peel of air-stored apples. While we did not observe an effect of the LOT on peel Ca and Mg concentration, a significant decrease in Ca and $\mathrm{Mg}$ cortex concentrations was determined after 2 months cold storage indicating a redistribution of mineral elements within the fruit as indicated by Perring and Pearson. ${ }^{23,24}$

The results obtained are interesting as BP-affected tissues accumulate high amounts of Ca and $\mathrm{Mg}^{6}$, and the LOT appeared to decrease the cortex concentration of both cations, 2 months after cold-storage. Since the occurrence of BP in apples has been related to Ca levels, ${ }^{25}$ it is likely that storage conditions may influence the rate of mineral element redistribution within the fruit as described by Perring and Pearson ${ }^{23,24}$ and may subsequently have an effect on the rate of BP development as observed after subjecting fruits to a LOT. However, the underlying physiological and metabolic processes taking place over storage and 
the potential effect of low $\mathrm{O}_{2}$ pre-treatments regarding the development of $\mathrm{BP}$, remain unclear and should be further investigated in the future.

\section{CONCLUSIONS}

Giving a 10-day low $\mathrm{O}_{2}, 20^{\circ} \mathrm{C}$ pre-treatment to bitter pit susceptible ‘Golden Reinders' apples immediately after harvest decreased the incidence and rate of development of bitter pit and preserved fruit quality after 4 months cold storage. While the underlying mechanisms are currently not fully understood and require further research efforts, application of a low $\mathrm{O}_{2}$ pretreatment prior to storage seems to be a promising strategy to retard the occurrence of bitter pit, which may even be commercially viable.

\section{ACKNOWLEDGEMENTS}

Work financed by DGA (PM005/2006) and INIA, PET2007-09-C5, co-financed by the European Social Fund. Work of Victoria Fernández is supported by a “Juan de la Cierva”MEC post-doctoral contract, co-financed by the European Social Fund.

\section{REFERENCES}

1. Val J, Monge E, Risco D and Blanco A, Effect of pre-harvest calcium sprays on calcium concentrations in the skin and flesh of apples. J. Plant Nutr. 31:1889-1905 (2008).

2. Ferguson IB and Watkins CB, Bitter pit in apple fruit. Hort. Rev. 11:289-355 (1989).

3. Saure MC, Calcium translocation to fleshy fruit: its mechanism and endogenous control. Sci. Hortic. 105:65-89 (2005).

4. Ferguson IB and Watkins CB, Cation distribution and balance in apple fruit in relation to calcium treatments for bitter pit. Sci. Hortic. 19:295-299 (1983). 
5. Ferguson IB and Watkins CB, Crop load affects mineral concentrations and incidence of bitter pit in `Cox's Orange Pippin`apple fruit. J. Amer. Soc. Hort. Sci 117:377-379 (1992).

6. Val J, Avances recientes en la investigación del bitter pit. Vida Rural 165:42-44 (2003).

7. Val J, Gracia MA, Blanco A, Monge E and Pérez M, Polypeptide pattern of apple tissues affected by calcium-related physiopathologies. Food Science \& Technology International 12:417-421 (2006).

8. Tonetto de Freitas S and Mitcham EJ, When calcium is not the primary cause of calcium deficiency, in Abtract Book of the 6th International Postharvest ISHS Symposium, Ed, Antalya (Turkey), p 96 (2009).

9. Park S, Cheng NH, Pittman JK, Yoo KS, Park J, Smith RH and Hirschi KD, Increased calcium levels and prolonged shelf life in tomatoes expressing Arabidopsis $\mathrm{H}^{+} / \mathrm{Ca}^{2+}$ transporters. Plant Physiol. 139:1194-1206 (2005).

10. Gorney JR and A.A. K, Low oxygen and elevated carbon dioxide atmospheres inhibit ethylene biosynthesis in preclimacteric and climacteric apple fruit. J. Amer. Soc. Hort. Sci 122:542-546 (1997).

11. Stow JR, Dover CJ and Genge PM, Control of ethylene biosynthesis and softening in ‘Cox’s Orange Pippin’ apples during low-ethylene, low-oxygen storage. Postharvest Biol. Technol. 18:215-225 (2000).

12. Chervin C, Kulkarni S, Kreidl S, Birrell F and D.A. G, A high temperature/low oxygen pulse improves cold storage disinfestation. Postharvest Biol. Technol. 10:239-245 (1997).

13. Ke D and Kader AA, External and internal factors influence fruit tolerance to lowoxygen atmospheres. J. Amer. Soc. Hort. Sci 117:913-918 (1992). 
14. Liu YB, Ultralow oxygen treatment for postharvest control of western flower thrips, Frankliniella occidentalis (Thysanoptera: Thripidae), on iceberg lettuce I. Effects of temperature, time, and oxygen level on insect mortality and lettuce quality. Postharvest Biol. Technol. 49:129-134 (2008).

15. Lurie S and Pesis E, Effect of acetaldehyde and anaerobiosis as postharvest treatments on the quality of peaches and nectarines. Postharvest Biol. Technol. 1:317-326 (1992).

16. Wang Z and Dilley DR, Initial low oxygen stress controls superficial scald of apples. Postharvest Biol. Technol. 18:201-213 (2000).

17. Zanella A, Control of apple superficial scald and ripening - a comparison between 1methylcyclopropene and diphenylamine postharvest treatments, initial low oxygen stress and ultra-low oxygen storage. Postharvest Biol. Technol. 27:69-78 (2003).

18. Pesis E, Ben-Arie R, Feygenberg O, Lichter A, Gadiyeva O, Antilofyev I and Uryupina T, A simple pretreatment with low $\mathrm{O}_{2}$ to alleviate superficial scald in Granny Smith apples. J. Sci. Food Agric. 87:1836-1844 (2007).

19. Pesis E, Ebeler S and Mitcham E, Post-harvest low oxygen pretreatment prevented superficial scald and bitter pit symptoms in 'Granny Smith' apples. HortSci. 42:882-883 (2007).

20. Gonzalez J, Arias E, Salvador ML and Oria R, Modelling of changes in atmosphere composition in fresh-cut peach packages due to temperature. Food Sci. Tech. Int. 14:109-116 (2008).

21. Blanco Braña A and Jackson JE, Effects of applying growth regulating hormones following fruit tree pruning. I: Effects of different types and concentrations of auxins and of GA4+7 and 6-benzylamino purine on shoot emergence and wound healing of apple trees. $J$. Hort. Sci. 57:17-30 (1982).

22. Perring MA, Redistribution of minerals in apple fruit during storage. Preliminary investigations with the variety Spartan. J Sci Food Agric 35:182-190 (1984) 
23. Perring MA and Pearson K, Redistribution of minerals in apple fruit during storage: The effect of storage atmosphere on calcium concentration. J Sci Food Agric 40:37-42 (1987) 24. Perring MA and Pearson K, Redistribution of minerals in apple fruit during storage: Effects of storage atmosphere on magnesium and phosphorus concentrations. J Sci Food Agric 43:109-119 (1988)

25. Perring MA, Incidence of bitter pit in relation to the calcium content of apples: Problems and paradoxes, a review. J Sci Food Agric 37:591-606 (1986) 


\section{Tables}

Table 1. Effect of a 10-day low $\mathrm{O}_{2}$ pre-treatment (LOT) to 'Golden Reinders' on the incidence of BP, and on the parameters resulting from the sigmoid fit of data over the storage period as compared to the results obtained of standard cold-stored apples (ST).

\begin{tabular}{lcccc}
\hline & & \multicolumn{3}{c}{ Model parameters } \\
\cline { 3 - 5 } Treatment & Bitter pit incidence (\%) & $\begin{array}{c}\text { Maximum BP } \\
\text { incidence (\%) }\end{array}$ & $\begin{array}{c}\text { Max. rate of BP } \\
\text { incidence }\left(\% \text { day }^{-1}\right)\end{array}$ & $\begin{array}{c}\text { Date of max. } \\
\text { rate }\left(\mathrm{DAH}^{*}\right)\end{array}$ \\
\hline LOT & $11.8 \pm 1.9(18.7 \pm 8.9)$ & $17.3 \pm 2.3$ & $0.87 \pm 0.28$ & $76.1 \pm 4.0$ \\
ST & $34.4 \pm 14.2(35.0 \pm 2.0)$ & $39.1 \pm 13.4$ & $1.04 \pm 0.52$ & $60.0 \pm 4.7$ \\
Significance & $* *$ & $*$ & $*$ & NS \\
\hline
\end{tabular}

${ }^{\text {a }}$ ANOVA carried out with the angular transformation. In brackets: transformed values.

NS: not significant; *: significant at $P \leq 0.05$; **: significant at $P \leq 0.01$.

Data are means $\pm \mathrm{SE}$.

${ }^{*}$ DHA, days after harvest 
Table 2. Fruit quality traits at harvest and after 4 month of cold storage. Apples were either subjected to a 10-day low $\mathrm{O}_{2}$ pre-treatment (LOT) or were directly cold-stored (ST).

\begin{tabular}{lcccccc}
\hline & Firmness & SSC & TA & \multicolumn{3}{c}{ Chromaticity values } \\
\cline { 6 - 8 } Treatments & $(\mathrm{N})$ & $(\%)$ & $\left(\mathrm{mg} \mathrm{L}^{-1}\right)$ & $\mathrm{L}$ & $\mathrm{a}^{*}$ & $\mathrm{~b}^{*}$ \\
\hline At harvest & & & & & & \\
Mean values & $68.5 \pm 0.7$ & $14.3 \pm 0.1$ & $5.5 \pm 0.2$ & $73.0 \pm 0.3$ & $-11.6 \pm 0.4$ & $41.4 \pm 0.2$ \\
After 4 months cold storage & & & & & & \\
LOT & $53.0 \pm 0.5$ & $14.1 \pm 0.1$ & $5.0 \pm 0.1$ & $75.6 \pm 0.2$ & $-3.8 \pm 0.2$ & $47.6 \pm 0.1$ \\
ST & $43.1 \pm 0.7$ & $12.2 \pm 0.1$ & $3.7 \pm 0.1$ & $72.7 \pm 0.4$ & $-7.8 \pm 0.5$ & $47.7 \pm 0.4$ \\
Significance & $* * *$ & $* * *$ & $* * *$ & $* * *$ & $* * *$ & $\mathrm{NS}$ \\
\hline
\end{tabular}

NS: not significant; ***: significant at $P \leq 0.005$

Data are means $\pm \mathrm{SE}$.

SSC, soluble solids content; TA, titratable acidity. 
Table 3. Calcium, $\mathrm{Mg}$ and $\mathrm{K}$ concentrations ( $\mathrm{g} \mathrm{kg}^{-1} \mathrm{FW}$ ) in the endo- and peel of 'Golden Reinders' apples at the time of harvest and 2 months after cold storage. Fruits were either subjected to 10-day low $\mathrm{O}_{2}$ pre-treatment (LOT) or were directly cold-stored (ST).

\begin{tabular}{|c|c|c|c|c|c|c|}
\hline \multirow[b]{2}{*}{ Treatments } & \multicolumn{3}{|c|}{$\begin{array}{l}\text { Cortex concentrations } \\
\qquad\left(\mathrm{g} \mathrm{kg} \mathrm{kg}^{-1} \mathrm{FW}\right)\end{array}$} & \multicolumn{3}{|c|}{$\begin{array}{l}\text { Peel concentrations } \\
\quad\left(\mathrm{g} \mathrm{kg}^{-1} \mathrm{FW}\right)\end{array}$} \\
\hline & $\mathrm{Ca}$ & $\mathrm{Mg}$ & $\mathrm{K}$ & $\mathrm{Ca}$ & $\mathrm{Mg}$ & $\mathrm{K}$ \\
\hline \multicolumn{7}{|l|}{ At harvest } \\
\hline Mean values & $0.029 \pm 0.004$ & $0.059 \pm 0.002$ & $0.870 \pm 0.017$ & $0.221 \pm 0.01$ & $0.15 \pm 0.003$ & $\begin{array}{c}1.104 \pm \\
0.02\end{array}$ \\
\hline \multicolumn{7}{|c|}{ After 2 months cold storage } \\
\hline LOT & $0.019 \pm 0.0008$ & $0.044 \pm 0.0008$ & $1.101 \pm 0.03$ & $0.104 \pm 0.004$ & $0.34 \pm 0.006$ & $1.92 \pm 0.04$ \\
\hline ST & $0.031 \pm 0.002$ & $0.050 \pm 0.001$ & $0.86 \pm 0.01$ & $0.12 \pm 0.004$ & $0.37 \pm 0.013$ & $1.81 \pm 0.03$ \\
\hline significance & $* * *$ & $*$ & $* * *$ & NS & NS & NS \\
\hline
\end{tabular}

NS: not significant; *: significant at $P \leq 0.05$; ***: significant at $P \leq 0.005$

Data are means \pm SE. 
Figures

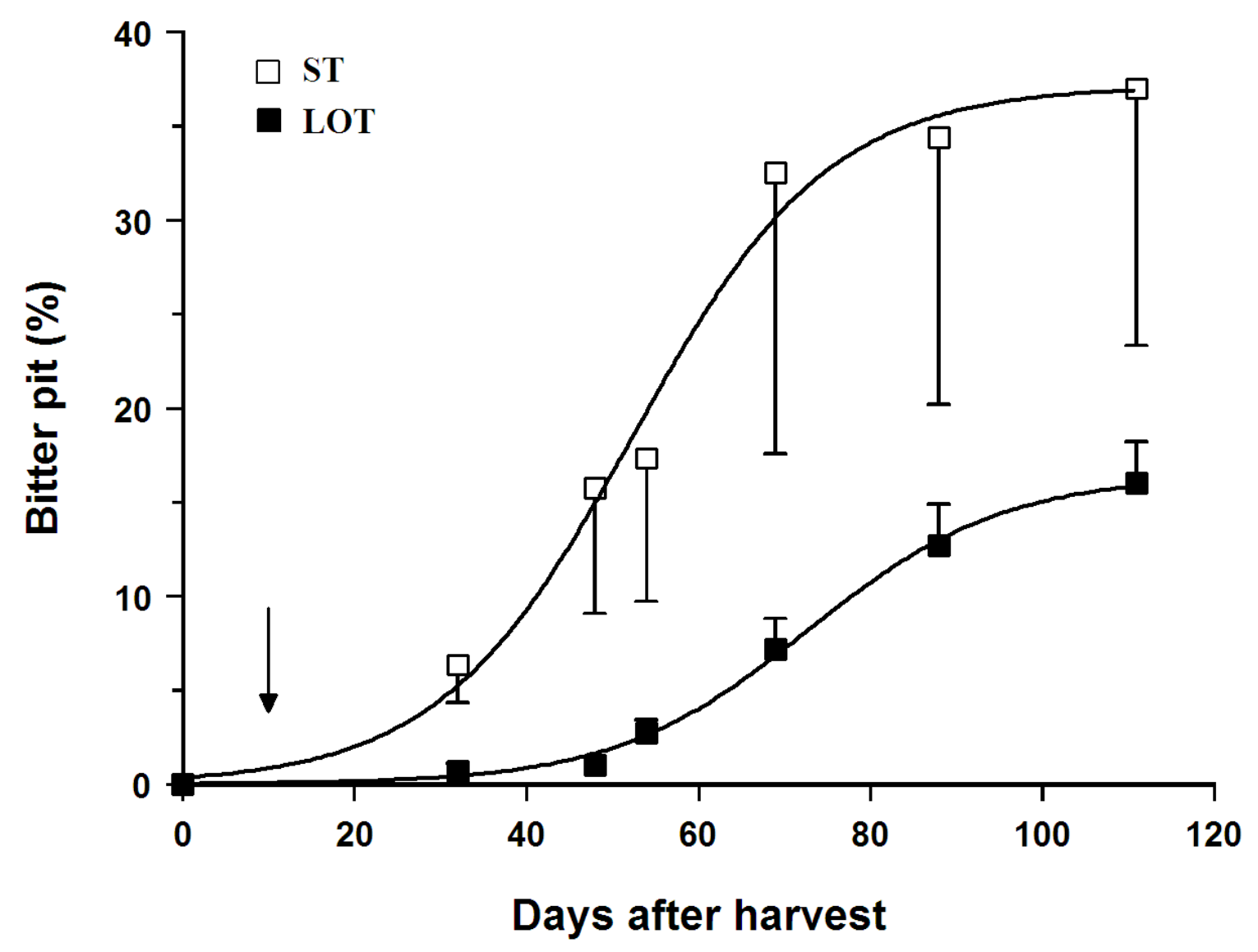

Figure 1. BP incidence during the cold storage period of 'Golden Reinders' apples. Fruits were either pre-treated at low- $\mathrm{O}_{2}$ and $20^{\circ} \mathrm{C}$ for 10 days (LOT; end of treatment indicated by the arrow) or directly cold-stored (ST). Vertical bars are means \pm SE. 


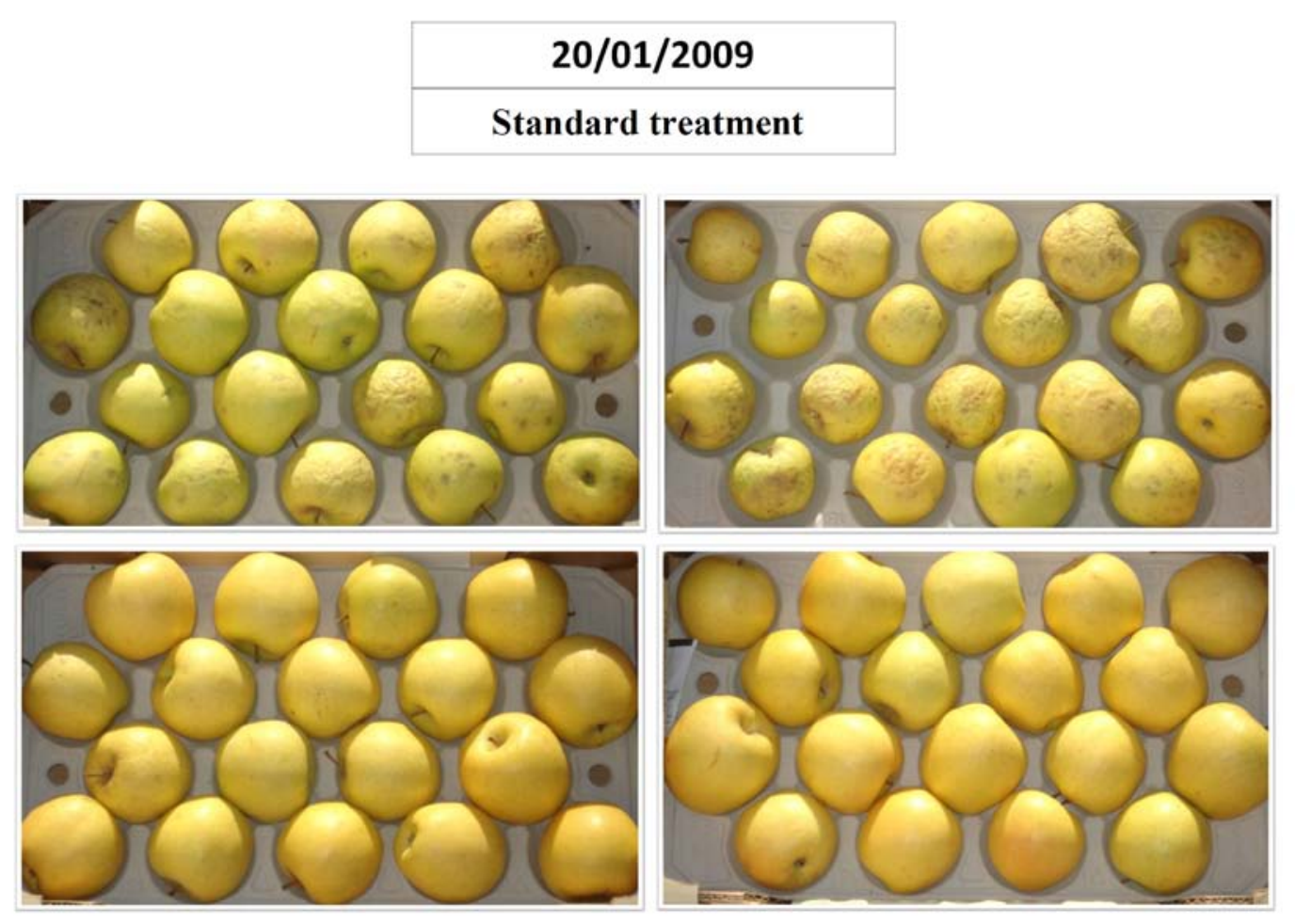

\section{Low $O$ treatment}

Figure 2. External appearance of 'Golden Reinders' apples 4 months after cold-storage. Fruits were either pre-treated at low- $\mathrm{O}_{2}, 20^{\circ} \mathrm{C}$ (LOT) for 10 days (lower images) or directly cold-stored (ST) (upper images). 